\title{
DEVELOPMENT, LONGEVITY, FECUNDITY, AND LIFE TABLE PARAMETERS OF Trissolcus basalis (WOLLASTON), EGG PARASITOID OF THE STINK GREEN BUG, Nezara viridula (L.) IN RELATION TO TEMPERATURE Abdel-Salam, A. H. ${ }^{1}$; Hala, A. K. El-Serafi ${ }^{1}$; M. E. El-Naggar ${ }^{2}$ and Walaa, A. Twafik ${ }^{2}$ \\ ${ }^{1}$ Economic Entomology Department, Faculty of Agriculture, Mansoura University, Mansoura 35516, Egypt. \\ E-mail: adhabdel@mans.edu.eg \\ 2 Plant Protection Research Institute, Agricultural Research Center, Ministry of Agriculture
}

\section{ABSTRACT}

The developmental time of immature stages, developmental rate, longevity, fecundity and life table parameters of Trissolcus basalis (Wollaston) were investigated at three temperatures $\left(24,28\right.$ and $\left.31^{\circ} \mathrm{C}\right)$. The data reveled that there was a significant variation in the developmental time of immature stages between the three tested temperatures. The higher developmental rate was recorded at $31^{\circ} \mathrm{C}$.

There were significant differences between the three temperatures in percentage of parasitized eggs and sex ratio, while there was no significant difference in percentage of successful parasitism. The female sex ratio was 4:1 (females: males) at 28 and $31^{\circ} \mathrm{C}$, while it was $3: 1$ at $24^{\circ} \mathrm{C}$

There was a significant difference in longevity of females. It was $14.40 \pm 1.43$, $13.40 \pm 0.46$ and $9.00 \pm 2.08$ at 24,28 and $31^{\circ} \mathrm{C}$, while there was no statistical variation in the fecundity of $T$. basalis females reared at the three tested temperatures. The simple linear regression between temperatures and longevity of $T$. basalis females indicated that there was a highly relationship between temperatures and longevity. In addition, there was a positive relationship between the temperatures and fecundity. The calculated value of (T) and (DT) was higher at $24^{\circ} \mathrm{C}$ than 28 and $31^{\circ} \mathrm{C}$. In contrast, GRR, $R_{0}, r_{m}$ and $\lambda$ values were higher at $31^{\circ} \mathrm{C}$ than 24 and $28^{\circ} \mathrm{C}$. The survivorship (Lx) for female age was higher $(0.82)$ at $28^{\circ} \mathrm{C}$ than at 24 and $31^{\circ} \mathrm{C}$.

There was a significant difference between ages of the host egg masses in choice and non-choice tests. The first age (one day old) was preferred than the other ages. Moreover, the parasitoid was able to parasitize the host eggs in all developmental ages. The present investigation provided useful information of some biological aspects of $T$. basalis. In conclusion, $T$. basalis appears to be a promising biological control option for controlling the green stink bug, $N$. viridula.

Keywords: Trissolcus basalis, Nezara viridula, developmental time, longevity, fecundity, life table parameters.

\section{INTRODUCTION}

The green stink bug, Nezara viridula (L.) (Hemiptera: Pentatomidae), is a highly polyphagous insect that is widely distributed in many temperate and tropical regions of the world (Jones, 1988; Todd, 1989; Odermatt et al., 2000 and Panizzi et al., 2000). It causes important economic damage to various field crops, including soybean, beans, corn, cotton, tomato, sweet pepper, eggplant, cucurbits, sunflowers and grape (Todd, 1989; Jackal et al., 1990; Ehler, 2000; Odermatt et al., 2000 and Panizzi et al., 2000). Both nymphs and adults feed on developing and mature fruit, often resulting in 
either direct loss or unmarketable produce, discoloration, stunting and shriveling of tissues (Clarke, 1990; Clarke and Walter, 1993; Ehler, 2000 and Odermatt et al., 2000). This pest is typically either bivoltine or multivoltine, and overwinters as a diapausing adult in above-ground habitats, such as beneath the bark of trees. Females deposit pale yellow eggs in large masses predominantly on the undersides of leaves. There are five nymphal instars (Todd, 1989; Ehler, 2000; Odermatt et al., 2000 and Panizzi et al., 2000).

Control of this pest is based on the intensive use of chemical pesticides, including carbamates, organophosphates and some pyrethroids. Massive use of insecticides not only increases production cost, it may also affect populations of beneficial insects and trigger pest resurgence problems (Panizzi et al., 2000 and Godoy et al., 2005).

Biological control, as a component within integrated pest management (IPM) programs, is a powerful pest control option in situations where chemical control is insufficient, impossible, or undesirable. Thus, techniques for mass production of some parasitoids may relatively help in solving the problem of $N$. viridula and reduce the hazard of pesticides to human and environment (Panizzi et al., 2000 and Godoy et al., 2005). Parasitoids are important biological control agents against $N$. viridula (Jones, 1988; Hoffmann et al., 1991 and Ehler, 2002). The egg parasitoid, Trissolcus basalis (Wollaston) (Hymenoptera: Scelionidae) is an important biological control agent of stinkbugs worldwide (Correa-Ferreira and Moscardi, 1995 and 1996; Ehler, 2002; Lenteren and Bueno, 2003 and Catalan and Verdu, 2005). It is well established and adapted in Egypt and is credited with the control of $N$. viridula. Releases of the egg parasitoid, $T$. basalis have successfully suppressed outbreaks of the green stinkbug (Correa-Ferreira and Moscardi, 1996).

The effects of temperature are often critical in determining the rate and success of the development of parasitoids. Typically, the development of parasitoids is prolonged in cooler environments and increased in warmer environments, up to a critical temperature (Orr et al., 1985 and Nakama and Foerster, 2001). Temperature is probably the most important physical environmental factor influencing the development, reproduction of insects, and regulates insect population dynamics, and seasonal occurrence. Numerous studies have illustrated the effect of temperature on the biological and population growth of $T$. basalis (Orr et al., 1985; Porta, 1992; Nakama and Foerster, 2001 and Catalan and Verdu, 2005).

However, scanty attention has been paid on the effect of temperatures on biological characteristics and life table parameters of the scelionid egg parasitoid, T. basalis for mass rearing and release. Therefore, the current investigation was conducted to study the influence of temperatures on biological attributes of $T$. basalis, as well as testing the effect of temperatures on life table parameters of this species. 


\section{MATERIAL AND METHODS}

\section{Host cultures:}

Pairs of $N$. viridula adults were collected by sweeping net from cowpea plants at the experimental farm of Faculty of Agriculture, Mansoura University and caged in 30 plastic containers $(0.5 \times 10 \mathrm{~cm})$ covered with muslin for ventilation. Adults were fed with cowpea leaves. Food was changed daily. Egg masses were collected daily to prevent cannibalism by adults.

\section{Parasitoid culture:}

Trissolcus basalis was cultured in the laboratory from $N$. viridula parasitized egg masses which collected from cowpea fields. Parasitoids were maintained in Petri-dishes supplied with sugar solution for food. The culture was kept at $28 \pm 2.0^{\circ} \mathrm{C}$ and $75.0 \pm 5.0$ relative humidity with 14 hours light: 10 hours dark photoperiod. A female parasitoid was used only once. The host egg masses were exposed to the parasitoid for $24 \mathrm{~h}$, then removed and placed in another Petri-dish for incubation. After the adult emergence, they were counted and sexed. The remaining eggs were dissected and eggs which perceptibly mature or immature forms of the parasitoid were identified and considered to be parasitized. The developmental times, percentage of parasitized eggs, successful parasitism and sex ratio were calculated.

\section{Effects of two constant temperatures $\left(24\right.$ and $\left.28^{\circ} \mathrm{C}\right)$ and fluctuated temperature}

The effects of two constant temperatures $\left(24\right.$ and $\left.28^{\circ} \mathrm{C}\right)$ and fluctuated temperature (average of room temperature $=31.0^{\circ} \mathrm{C}$ ) on the developmental time and rate (1/developmental time) (Omakar and James, 2004) of immature stages, emergence rate, sex ratio, longevity, and fecundity of females were determined. Five egg masses of $N$. viridula were offered to the females for parasitization. Each temperature treatment was replicated five times. Each female was used as a replicate. After the parasitization, parasitoids were removed and parasitized eggs were cultured under the same temperature condition until the immature developed. Developmental time, percentage of adult emergence, longevity and fecundity of females and sex ratio were recorded. Fecundity was expressed as the sum of emerged parasitoids plus parasitized eggs from which no parasitoids emerged. Parasitized eggs are easily recognized by the dark color assumed by the eggs five days after parasitism. Total of parasitized eggs per female and sex ratio were recorded. The effects of temperature on life table parameters were calculated using a BASIC computer program (Abou-Setta et al. 1986) for females reared on $24,28^{\circ} \mathrm{C}$ and fluctuated temperature $\left(31^{\circ} \mathrm{C}\right)$. This computer program is based on Birch's method (1948) for the calculation of an animal's life table. Effect of temperature on percentage of parasitized eggs, number of emerged adults, percentage of successful parasitism, the developmental time for immature stags, longevity of female, sex ratio and the fecundity of females was assessed by constructing a life table, using rates of age-specific ( $(\mathrm{Kx})$, and fecundity $(\mathrm{Mx})$ for each age interval $(\mathrm{x})$. The mean generation time $(T)$, gross reproductive rate $(G R R)(=\Sigma M x)$, the net 
reproductive increase $\left(R_{0}\right)$ the intrinsic rate of increase $\left(r_{m}\right)$, and the finite rate of increase $(\lambda)$. The doubling time (DT) was calculated according to Mackauer's method (Mackauer, 1983). The life tables were prepared from data recorded daily on developmental time (egg to first egg laid), sex ratio, the number of deposited eggs, the fraction of eggs reaching maturity, and the survival of females. Interval of one day was chosen as the age classes for constructing the life table.

\section{Choice and non-choice tests}

To test the preference for any age of host eggs (choice test), four egg masses of different ages (one day, two, three, and four days old) were offered simultaneously to single mated females. In non-choice test, four egg masses of the same age (one day, two, three, and four days old) were offered simultaneously to single mated females. Each egg mass was considered to be a replicate and placed in a plastic container. Females were removed from the plastic containers after $48 \mathrm{~h}$. The number of parasitized eggs, and the number of emerged adult was determined. All tests were done under natural photoperiod at room conditions during July and August, 2006.

\section{Data analysis}

All experimental data concerning the developmental times, successful parasitism, longevity, and fecundity were analyzed with one-way analysis of variance (ANOVA). Comparisons of means of biological characters were made with the Duncan's Multiple Range Test (Costat Software, 1990).

\section{RESULTS AND DISCUSSION}

\section{Developmental time of immature stages}

Analysis of variance (ANOVA) indicated that there were significant differences between the three temperatures in egg-larval stages, pupal stage and total of immature stages, with exception of egg-larval stages at 28 and $31^{\circ} \mathrm{C}$ (Table 1). In addition, the data in the same table showed that the average developmental time of the total immature stages was $17.84 \pm 0.29$, $11.68 \pm 0.22$ and $9.28 \pm 0.16$ days at 24,28 and $31^{\circ} \mathrm{C}$, respectively. The developmental rate was better at $31^{\circ} \mathrm{C}(0.108)$ than at 24 and $28^{\circ} \mathrm{C}$.

Table 1. Average developmental time (mean $\pm S E$ ) in days of immature stages of $T$. basalis reared at three temperatures.

\begin{tabular}{|c|c|c|c|c|}
\hline \multirow{2}{*}{ Temperature } & \multicolumn{3}{|c|}{ Immature stages } & $\begin{array}{c}\text { Developmental } \\
\text { Rate }\end{array}$ \\
\cline { 2 - 4 } & Egg-larval stages & Pupal stage & Total & 0.056 \\
\hline $24^{\circ} \mathrm{C}$ & $12.6 \pm$ & $5.72 \pm$ & $17.84 \pm$ & \\
\hline $28^{\circ} \mathrm{C}$ & $0.29 \mathrm{a}$ & $0.27 \mathrm{a}$ & $0.29 \mathrm{a}$ & \\
& $7.12 \pm$ & $4.56 \pm$ & $11.68 \pm$ & 0.086 \\
& $0.18 \mathrm{~b}$ & $0.21 \mathrm{~b}$ & $0.22 \mathrm{~b}$ & \\
\hline $31^{\circ} \mathrm{C}$ & $5.68 \pm$ & $3.64 \pm$ & $9.28 \pm$ & 0.108 \\
& $0.18 \mathrm{~b}$ & $0.15 \mathrm{C}$ & $0.16 \mathrm{c}$ & \\
\hline
\end{tabular}

Means followed by the same letter in a column are not significantly different at the $5 \%$ level of probability (Duncan's Multiple Range Test). 
The data in Table (1) clearly indicated that the immature stages took a longer time at $24^{\circ} \mathrm{C}$ than at $28^{\circ} \mathrm{C}$. Whereas, it was shortest at $31^{\circ} \mathrm{C}$. Orr et al (1985) mentioned that $T$. basalis completed its development at all temperatures ranging from 15 to $36^{\circ} \mathrm{C}$ and eight constant relative humidity ranging from 64 to $100 \%$ R. H. Meanwhile, Porta (1992) noted that the developmental time for $T$. basalis from egg to adult was $13.5 \pm 1.6$ days at $26^{\circ} \mathrm{C} \pm 3.0,75.0 \pm 10.0 \% R$. $H$. and $L: D(16: 8)$.

The percentage of parasitized eggs, successful parasitism and sex ratio In Table (2), there were significant differences between the three temperatures in percentage of parasitized eggs and sex ratio, while there were no significant differences between the three temperatures in percentage of successful parasitism. According to the data in Table (2), the percentage of parasitized eggs, and the percentage of successful parasitism of $T$. basalis was greater at $28^{\circ} \mathrm{C}$ and $31^{\circ} \mathrm{C}$ than $24^{\circ} \mathrm{C}$. The female sex ratio was $4: 1$ (females: males) at 28 and $31^{\circ} \mathrm{C}$, while it was $3: 1$ at $24^{\circ} \mathrm{C}$. Similar results were obtained by Orr et al. (1985) and Porta (1992) who reported that the percentage of parasitoids reaching the adult stage, and the percentage of adult emergence of $T$. basalis were significantly greater at both upper and lower extreme temperatures, and the sex ratio for $T$. basalis reared in the laboratory at $26 \pm 3.0^{\circ} \mathrm{C}, 75.0 \pm 10.0 \% \mathrm{R}$. H. and LD 16:8 was $4: 1$.

Table 2. Percentage of parasitized eggs, successful parasitism and sex ratio of $T$. basalis reared at three temperatures.

\begin{tabular}{|c|c|c|c|}
\hline \multirow[b]{2}{*}{ Parameter } & \multicolumn{3}{|c|}{ Temperature } \\
\hline & $24^{\circ} \mathrm{C}$ & $28^{\circ} \mathrm{C}$ & $31^{\circ} \mathrm{C}$ \\
\hline Parasitized eggs \% & $79.47 \quad b$ & $90.25 \mathrm{a}$ & $82.29 \mathrm{ab}$ \\
\hline Successful parasitism \% & 69.91 a & 82.14 & $80.93 \mathrm{a}$ \\
\hline Sex ratio & $75.50 \mathrm{~b}$ & 80.44 & 80.90 \\
\hline
\end{tabular}

Means followed by the same letter in a row between the three temperatures are not significantly different at the $5 \%$ level of probability (Duncan's Multiple Range Test).

Simple linear regression between temperatures (independent variable $\mathrm{X}$ ) and percentage of parasitized eggs (dependent variable $\mathrm{Y}$ ) of $T$. basalis females yielded $R^{2}=0.6683$. The regression equation was derived: the percentage of parasitized eggs $(Y)=122.78-7.2147(X)$. This equation indicated that there was a relationship between temperatures and percentage of parasitized eggs (Fig. 1). Concerning the simple linear regression between temperatures and percentage of successful parasitism, the value of $R^{2}$ was 0.7485 and the regression equation was $Y=124.24-7.0865 X$. This equation indicated that there was a positive relationship between the temperatures and percentage of successful parasitism which means that the percentage of successful parasitism gradually increased as the temperatures increased (Fig. 2) Whereas, the simple linear regression between temperatures and sex ratio: $(Y)=1.1763-0.0687(X)\left(R^{2}=0.691\right)$ (Fig. 3 ). 


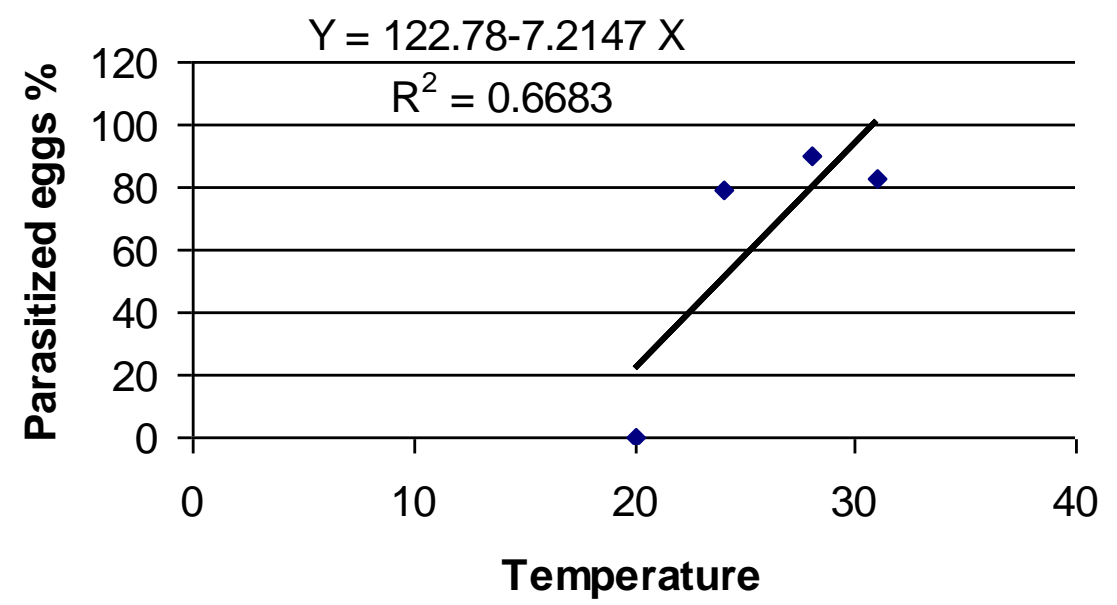

Fig. 1. Simple linear regression between temperatures $(X)$ and $\%$ of parasitized eggs $(Y)$ of $T$. basalis at 24,28 and $31^{\circ} \mathrm{C}$.

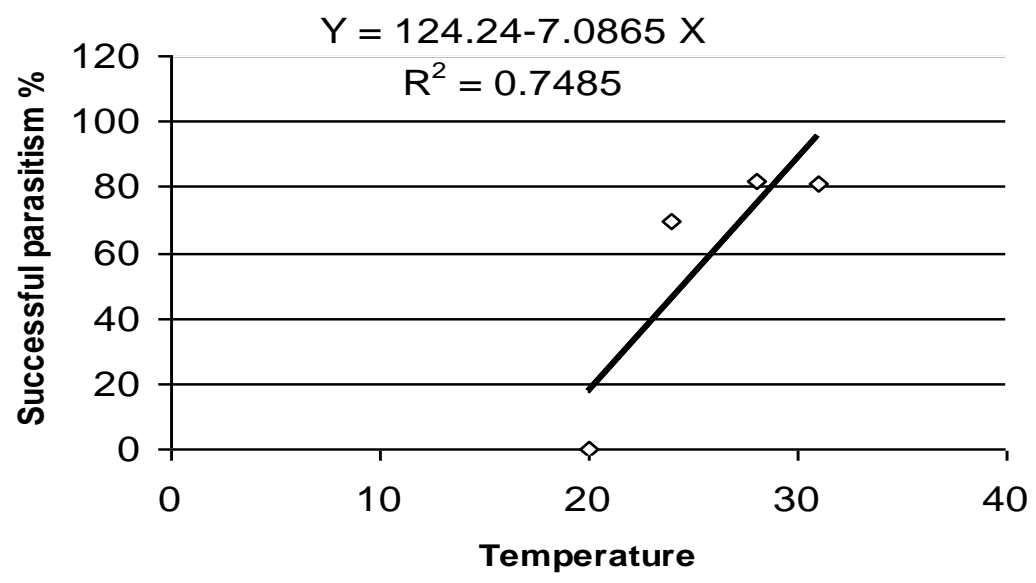

Fig.2. Simple linear regression between temperatures $(X)$ and successful parasitism $(\mathrm{Y})$ of $T$. basalis at 24,28 and $31^{\circ} \mathrm{C}$. 


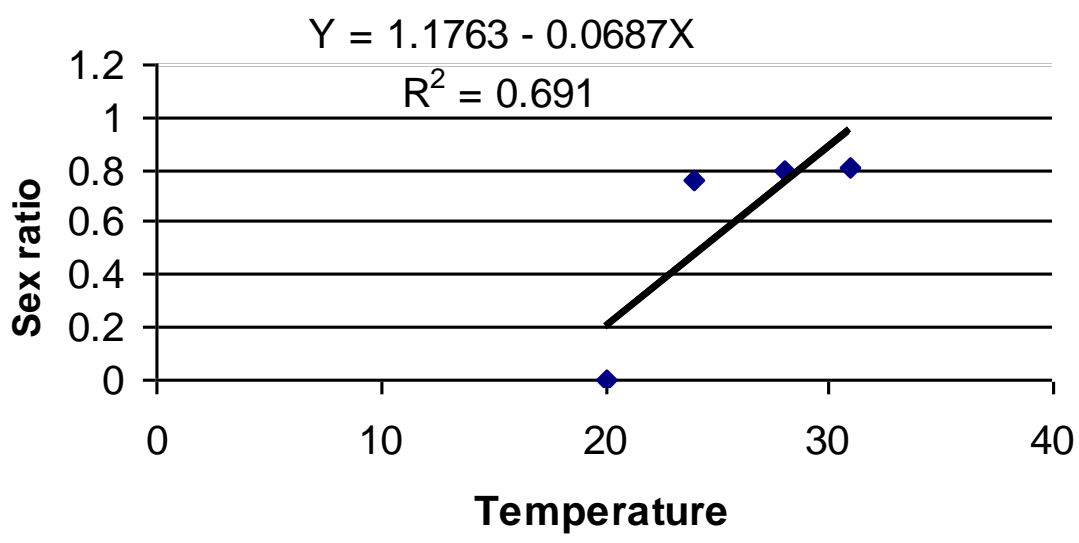

Fig. 3. Simple linear regression between temperatures $(X)$ and sex ratio $(\mathrm{Y})$ of $T$. basalis at 24,28 and $31^{\circ} \mathrm{C}$.

\section{Longevity and fecundity of females}

Based on the statistical analysis, there was a significant difference in longevity (Table 3 ). It was $14.40 \pm 1.43,13.40 \pm 0.46$ and $9.00 \pm 2.08$ at 24,28 and $31^{\circ} \mathrm{C}$. The simple linear regression between temperatures and longevity (dependent variable $Y$ ) of $T$. basalis females reared at 24,28 and $31^{\circ} \mathrm{C}$ yielded $R^{2}=0.7913$. The regression equation was: Female longevity $(Y)=$ 27.172-1.5076 temperatures $(X)$. This equation indicated that there was a highly relationship between temperatures and longevity (Fig. 4).

The ANOVA indicated that there was no statistical variation in the fecundity for $T$. basalis females reared at the three tested temperatures (Table 3).

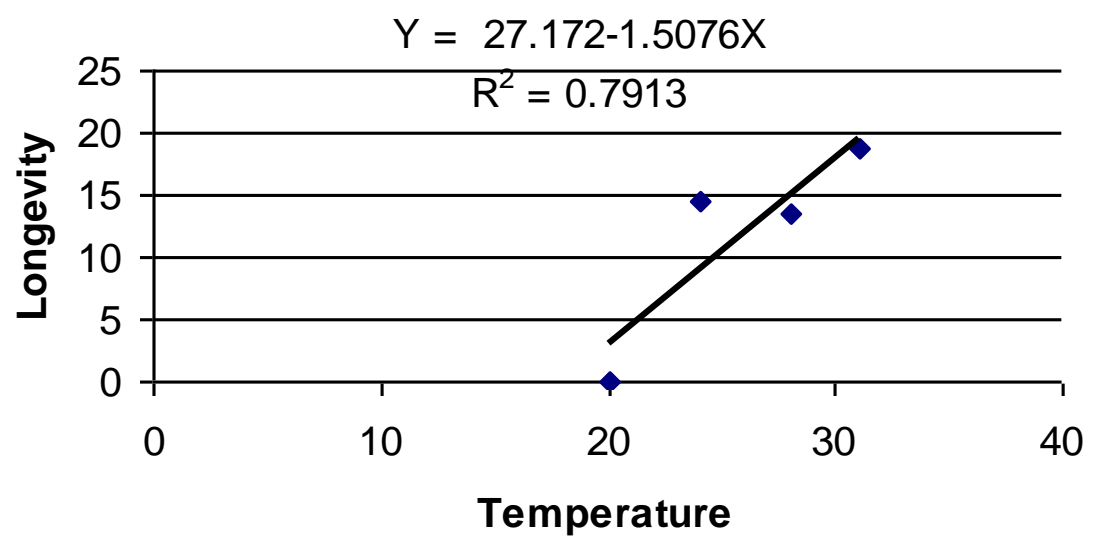

Fig. 4. Simple linear regression between temperatures $(X)$ and longevity (Y) of $T$. basalis at 24,28 and $31^{\circ} \mathrm{C}$. 
The following regression equation was calculated for $T$. basalis females between the temperatures and fecundity $(Y)=344.3-19.435(X)\left(R^{2}=0.777\right)$. From this equation, there was a positive relationship (Fig. 5). Catalan and Verdu (2005) noted that the life cycle of $T$. basalis females was 14.48 days and the oviposition of $T$. basalis was recorded early in the life cycle of the parasitoid.

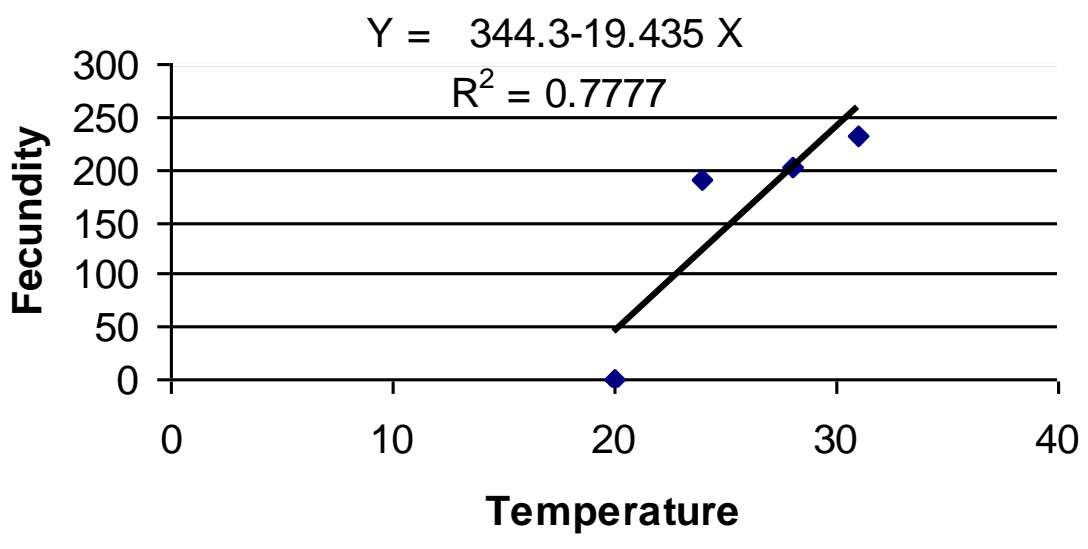

Fig. 5. Simple linear regression between temperatures $(X)$ and fecundity (Y) of $T$. basalis at 24,28 and $31^{\circ} \mathrm{C}$.

Table .3. Longevity and fecundity (mean \pm SE) of $T$. basalis females reared at three temperatures.

\begin{tabular}{|c|c|c|c|}
\hline \multirow{2}{*}{ Parameter } & \multicolumn{3}{|c|}{ Temperature } \\
\cline { 2 - 4 } & $\mathbf{2 4}^{\circ} \mathbf{C}$ & $\mathbf{2 8}^{\circ} \mathbf{C}$ & $\mathbf{3 1}^{\circ} \mathbf{C}$ \\
\hline Longevity & $14.40 \pm 1.43 \mathrm{a}$ & $13.40 \pm 0.46 \mathrm{ab}$ & $9.00 \pm 2.08 \mathrm{~b}$ \\
\hline Fecundity & $191.00 \pm 11.09 \mathrm{a}$ & $202.00 \pm 6.64 \mathrm{a}$ & $231.60 \pm 18.20 \mathrm{a}$ \\
\hline
\end{tabular}

Means followed by the same letter in a row between the three temperatures for $T$. basalis are not significantly different at the $5 \%$ level of probability (Duncan's Multiple Range Test).

\section{Life table parameters}

Data presented in Table (4) illustrated the life table parameters of $T$. basalis female reared on $N$. viridula eggs under three temperatures. The mean generation time was $22.26,15.19$ and 12.73 days at 24,28 and $31^{\circ} \mathrm{C}$, respectively. The population could be doubled (DT) every $3.34,2.15$ and 1.76 days at 24,28 and $31^{\circ} \mathrm{C}$, respectively. The values of net reproductive rate $\left(R_{0}\right)$, intrinsic rate of increase $\left(r_{m}\right)$, finite rate of increase $(\lambda)$ and the gross reproductive rate (GRR) were higher at $31^{\circ} \mathrm{C}$ than at 24 and $28^{\circ} \mathrm{C}$.

From the data illustrated in Figs. 6,7 and 8 , it could be noted that the survivorship (Lx) for female age was higher $(0.82)$ at $28^{\circ} \mathrm{C}$ than at 24 and $31^{\circ} \mathrm{C}$. The maximum reproduction rate per female per day $(\mathrm{Mx})$ was 28.39 on the second day at $24^{\circ} \mathrm{C}$. Moreover, it was 36.04 on the third day at $28^{\circ} \mathrm{C}$. While, at $31^{\circ} \mathrm{C}, \mathrm{Mx}$ was 36.24 on the first day. 
Table 4. Life table parameters of $T$. basalis reared on $N$. viridula eggs at three temperatures.

\begin{tabular}{|l|c|c|c|}
\hline \multirow{2}{*}{\multicolumn{1}{|c|}{ Life table parameters }} & \multicolumn{3}{c|}{ Temperature } \\
\cline { 2 - 4 } & $\mathbf{2 4}^{\circ} \mathbf{C}$ & $\mathbf{2 8}^{\circ} \mathbf{C}$ & $\mathbf{3 1}^{\circ} \mathbf{C}$ \\
\hline Mean generation time (T) (in days ) & 22.26 & 15.19 & 12.73 \\
\hline Doubling time (DT) (in days ) & 3.34 & 2.15 & 1.76 \\
\hline Net reproductive rate $\left(\mathrm{R}_{\mathrm{o}}\right)$ & 100.81 & 133.46 & 151.63 \\
\hline Intrinsic rate of increase $\left(\mathrm{r}_{\mathrm{m}}\right)$ & 0.207 & 0.322 & 0.394 \\
\hline Finite rate of increase $(\lambda)$ & 1.230 & 1.379 & 1.483 \\
\hline Gross reproductive rate (GRR) & 157.57 & 162.75 & 169.83 \\
\hline
\end{tabular}

$$
-x-M X \leadsto-L X
$$

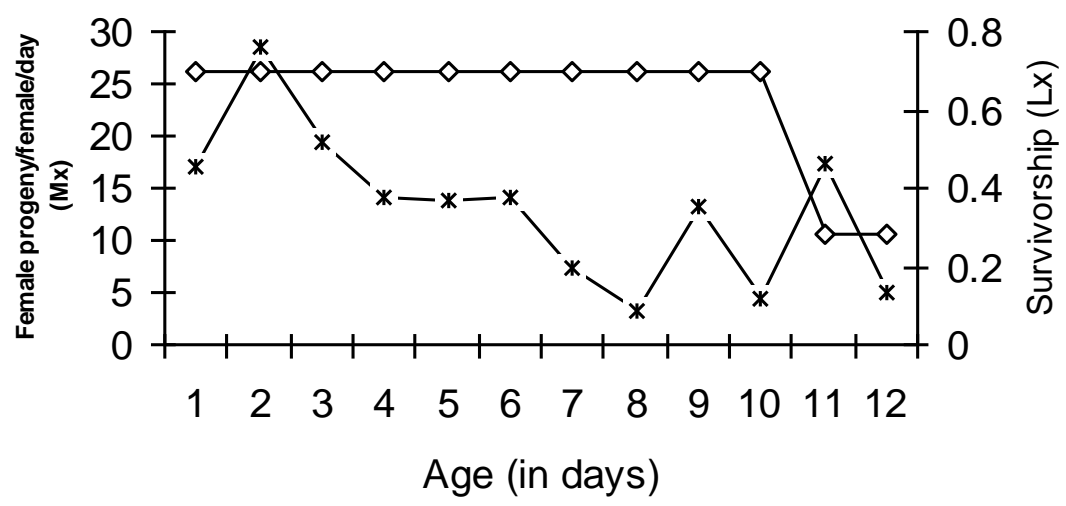

Fig. 6. Age-specific fecundity (Mx) and survivorship (Lx) of T. basalis female reared on $N$. viridula eggs at $24^{\circ} \mathrm{C}$.

$$
-x-M X \leadsto L X
$$

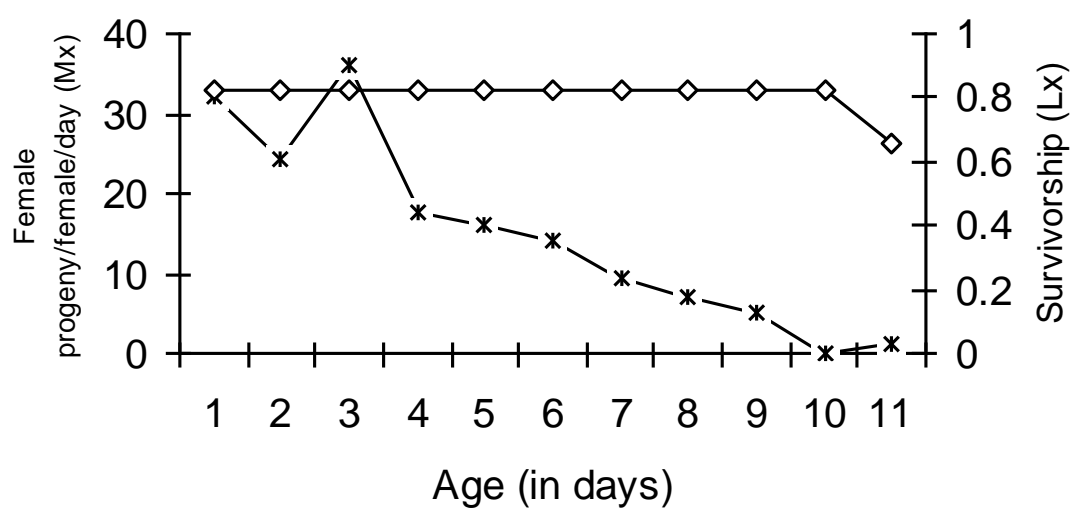

Fig. 7. Age-specific fecundity (Mx) and survivorship (Lx) of T. basalis female reared on $N$. viridula eggs at $28^{\circ} \mathrm{C}$. 


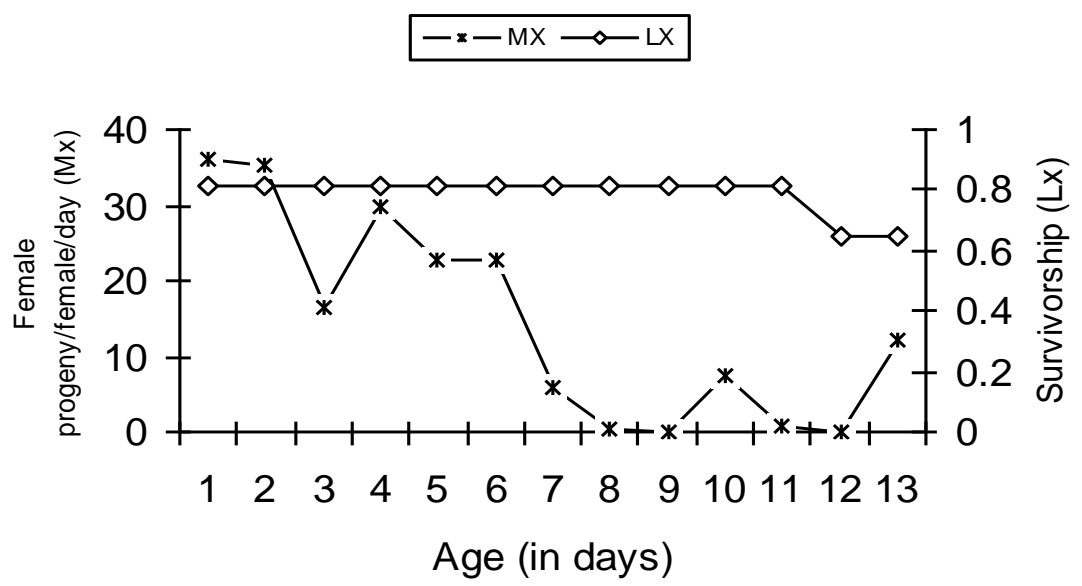

Fig. 8. Age-specific fecundity (Mx) and survivorship (Lx) of T. basalis female reared on $N$. viridula eggs at $31^{\circ} \mathrm{C}$.

\section{Choice and non-choice tests}

As shown in Figs. 9 and 10, there was a significant difference between eggs ages in choice and non-choice tests. The first age (one day old) was preferred than the other ages. Moreover, the parasitoid was able to parasitize the host eggs in all developmental ages, while the percentage of parasitism on host eggs in earlier ages was higher than in later developmental ages. The parasitism percentages in choice test were 65.80, $54.51,16.67$ and $5.31 \%$ for one day, two, three and four days old, respectively. Moreira and Becker (1986) found that the parasitoids preferred eggs at the earlier stages of development, although later stages were also attacked.

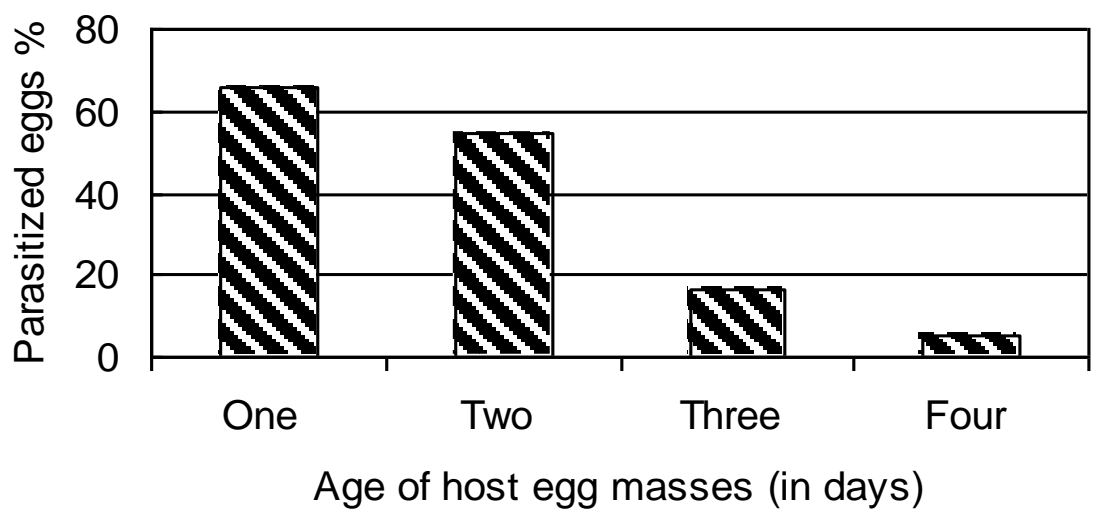

Fig. 9. Effect of age of $N$. viridula egg masses in choice test to parasitism by $T$. basalis under laboratory conditions. 


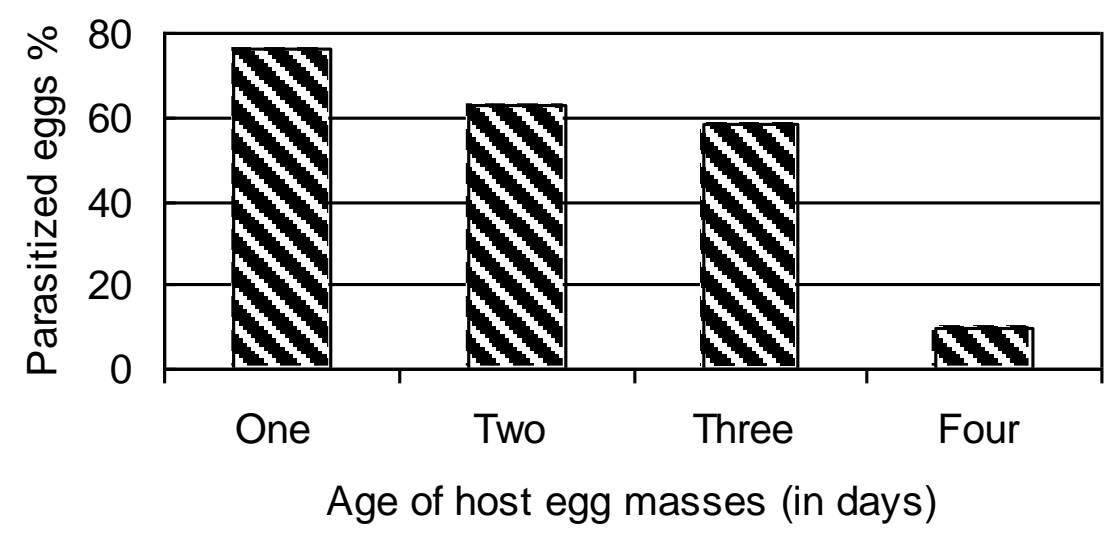

Fig.10. Effect of age of $N$. viridula egg masses in non choice test to parasitism by $T$. basalis under laboratory conditions.

\section{REFERENCES}

Abou-Setta, M. M.; Sorrell, R. W. and Childers, C. C. 1986. Life 48: A basic computer program to calculate life table parameters for an insect or mite species. Fla. Entomol. 69: 690-697.

Birch, L. C. 1948. The intrinsic rate of natural increase of an insect population. J. Anim. Ecol. 17:15-26.

Catalan, J. and Verdu, M. J. 2005. An evaluation of two egg parasitoids of Nezara viridula. Boletin de Sanidad Vegetal 31: 187-197.

Clarke, A.R. 1990. The control of Nezara viridula (L.) with introduced egg parasitoids in Australia. A review of a 'Landmark' example of classical biological control. Aust. J. Agric. Res. 41: 1127-1146.

Clarke, A.R. and Walter, G.H. 1993. Biological control of green vegetable bug (Nezara viridula [L.]) in eastern Australia: current status and perspectives. In: S.A. Corey, D.J. Dall and W.M. Milne (eds), Pest Control and Sustainable Agriculture. CSIRO Div. Entomol., Canberra. pp. 223-225.

Correa-Ferreira, B. S, and Moscardi, F. 1995. Seasonal occurrence and host spectrum of egg parasitoids associated with soybean stink bugs. Biol Contr. 5:196-202

Correa-Ferreira, B. S., and Moscardi, F. 1996. Biological control of soybean stink bugs by inoculative releases of Trissolcus basalis. Entomol. Exp. Appl. 79: 1-7.

Costat Software. 1990. Microcomputer program analysis, Version 4.20, CoHort Software, Berkely, CA, USA.

Ehler, L.E., 2000. Farmscape ecology of stink bugs in Northern California. Mem., Thomas Say Publ. Entomol., Entomol. Soc. Am. Press, Lanham, MD. 
Ehler, L. E. 2002. An evaluation of some natural enemies of Nezara viridula in northern California. BioControl. 47: 309-325.

Godoy, K. B.; Galli, J. C.; Avila, C. J. and Correa-Ferreira, B. S. 2005. Selectivity of insecticides to Trissolcus basalis (Woll.) (Hym.: Scelionidae) in the laboratory. Revista de Agricultura 80: 300-315.

Hoffmann, M. P., Davidson, N. A. ; Wilson, L. T. ; Ehler, L. E. ; Jones, W. A. and Zalom, F. G. 1991. Imported wasp helps control southern green stink bug. California Agriculture 45(3): 20-22.

Jackal, L. E. N., Panizzi, A. R. ; Kundu, G. G. and Srivastava, K. P. 1990. Insect pests of soybean in the tropics, pp. 91-156. In S. R. Singh [ed.], Insect Pests of Tropical Food Legumes. John Wiley \& Sons, Chichester, U.K. $451 \mathrm{pp}$.

Jones, W. A. 1988. World review of the parasitoids of the southern green stink bug, Nezara viridula (L.) (Heteroptera: Pentatomidae). Ann. Entomol. Soc. Amer. 81: 262-273.

Lenteren, J. C. and Bueno, V. H. P. 2003. Augmentative biological control of arthropods in Latin America. BioControl 48: 123-139.

Mackauer, M. 1983. Quantitive assessment of Aphidius smithi (Hymenoptera: Aphidiidae): fecundity, intrinsic rate of increase, and functional response. Can. Entomol. 115:399-415.

Moreira, G. R. P. and Becker, M. 1986. Mortality of Nezara viridula (L.) (Heteroptera: Pentatomidae) in the egg stage in a soybean field: II . Parasitoids. Anais. Da. Sociedade. Entomol. Do. Brazil 15: 291-308

Nakama, P. A. and Foerster, L. A. 2001. Effect of alternating temperatures on the development and emergence of Trissolcus basalis (Wollaston) and Telenomus podisi Ashmead (Hymenoptera: Scelionidae). Neotropical Entomology 30: 269-275.

Odermatt, S.; Lenfant, C. and Klapwijk, J. 2000. Biological control of Nezara viridula on eggplant with an egg parasitoid Trissolcus basalis (Wollaston). Bulletin OILB/SROP 23: 213-217.

Omakar and James, B. E. 2004. Influence of prey species on immature survival, development, predation, and reproduction of Coccinella transversalis Fabricius (Col., Coccinellidae). J. Appl. Ent. 128: 150-157.

Orr, D. B.; Boethel, D. J. and Jones, W. A. 1985. Development and emergence of Telenomus chloropus and Trissolcus basalis (Hymenoptera: Scelionidae) at various temperatures and relative humidity. Ann. Ent. Soc. Amer. 78: 615-619.

Panizzi, A. R., Mcpherson, J. E.; James, D. G.; Avahery, M. and Mcpherson, R. M. 2000. Chapter 13: Stink bugs (Pentatomidae), pp. 421-474 In C. W. Schaefer, and A. R. Panizzi [eds.], Heteroptera of Economic Importance. CRC Press, Boca Raton, FL. 828 pp.

Porta, N. C. L. 1992. Population dynamics of Trissolcus basalis (Wollaston) (Hymenoptera:Scelionidae). I. Life statistics. Revista. de. A. Sociedad .Entomol. 50: 267-275.

Todd, J. W. 1989. Ecology and behavior of Nezara viridula. Annu. Rev. Entomol. 34: 273-292. 


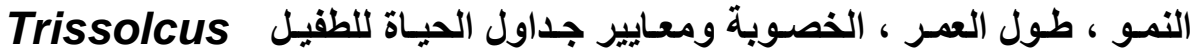

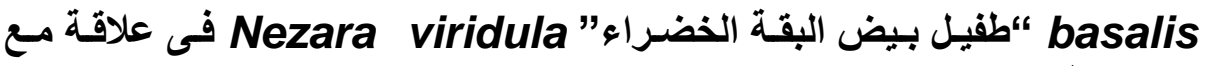

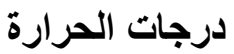

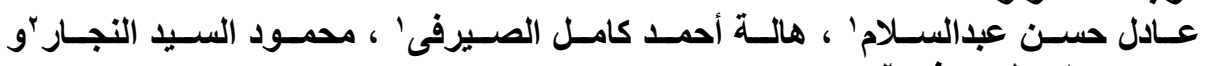

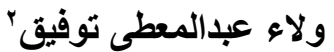

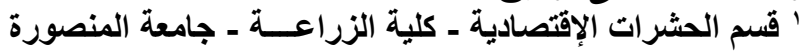
'معهذ بحوث وقاية النباتات ـ مركز البحوث الزراعية - وزارة الزراعة

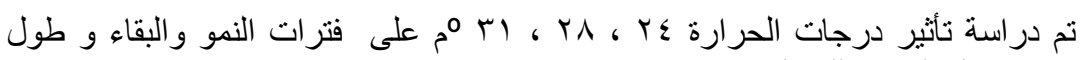

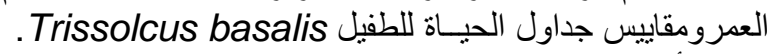

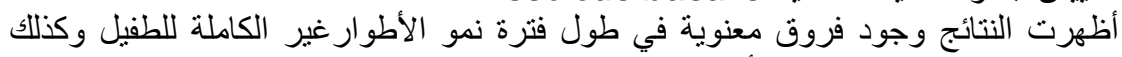

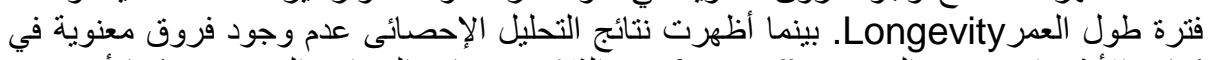

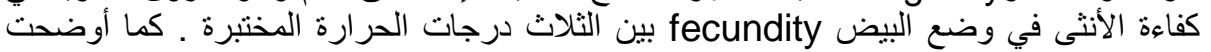

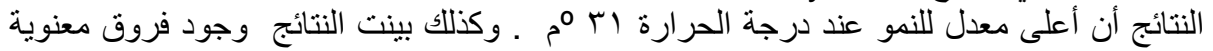
بين نسبة التطفل ،النسبة الجنسية ودرجات الحرارة المختبرة حيث كانت النسبة النسبة الجنسية للإناث

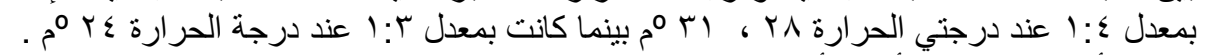

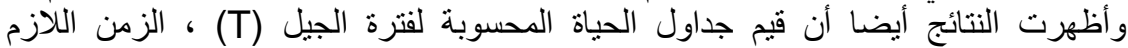

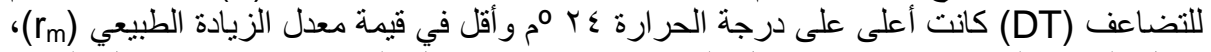

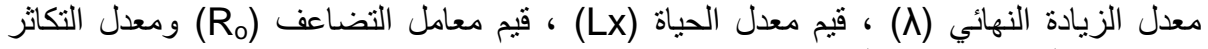
على نس درجة الحرارة.

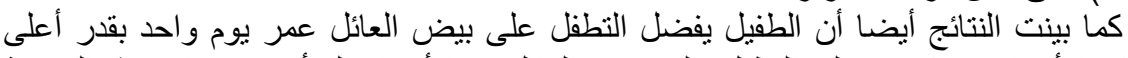

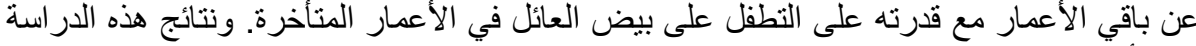

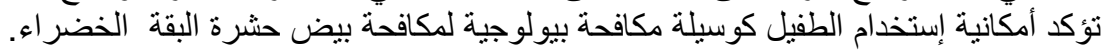

